\title{
DECISION SUPPORT SYSTEM FOR COMPREHENSIVE APPRAISAL OF COASTAL RESORT PROJECTS IN JEDDAH
}

\author{
Mohammad Abdul Rahman Kattan+, Mahmoud A. Taha*, \\ and Abdullah Mostafa Mohorjy \\ + Project Director for Girls Faculties, King Abdul Aziz University, \\ Kingdom of Saudi Arabia \\ * Associate Professor, Civil Engineering Department, Construction \\ Management Program, King Abdul Aziz University, on leave from \\ Structural Engineering Department, Cairo University, Egypt. \\ ** Professor of Water Resources \& Environmental Engineering, King \\ Abdul Aziz University, Kingdom of Saudi Arabia
}

(Received May 7, 2011 Accepted May 21, 2011)

Project evaluation has to consider financial and environmental impacts including human, physical and ecological. Currently, the evaluation process in the city of Jeddah, Kingdom of Saudi Arabia (KSA), does not take all these impacts into consideration despite the issuance of the general environmental regulations in 2001 that necessitate the implementation of an Environmental Impact Assessment (EIA) studies at the feasibility stage of projects, which might cause adverse effects on environment.

The main objective of this research is to develop a Decision Support System (DSS) that integrates these impacts into one model to evaluate coastal resort projects along Red Sea coast at feasibility stage.

The proposed system is composed of two main components, the environmental and the financial assessment. First, the system assesses the environmental impacts of the project using fuzzy logic technique by calculating the Decision Making Coefficient (DMC). The DMC value is compared to the baseline of the city of Jeddah, which is developed in this research. Those projects that have DMC values greater than the baseline of Jeddah, suitable mitigation measures should be proposed to eliminate their adverse environmental impacts. Second, the system evaluates financially the projects that have no adverse environmental impacts by calculating Net Present Value (NPV), Internal Rate of Return (IRR), Payback Period (PBP), Profitability Index (PI), Debt Service Coverage Ratio (DSCR), and Mitigation Cost/Project Cost (MC/PC).

The system is validated using three existing coastal resort projects in the city of Jeddah. The validation results showed that the three case study projects were environmentally and financially feasible.

KEYWORDS: Environmental Impact Assessment, Financial Assessment, Uncertainty, Decision Support System

\section{I - INTRODUCTION}

Project appraisal begins by searching for promising ideas to identify potential projects. Identification of such an opportunity is based on the market analysis of the project and its projected supply and demand scenario. Technical analysis is then carried out to 
outline the basic elements of the potential project along with other few alternative scenarios with respect to project site, technology, material and implementation method (Dey 2005). Finally, project evaluation determines the project for investment based on the financial and environmental impacts including human, physical and ecological. Theoretically speaking, this evaluation process represents a comprehensive appraisal solution to both private and public sector practitioners. For this reason, the government of the Kingdom of Saudi Arabia (KSA) represented by the General Presidency of Meteorology and Environment (PME) issued in 2001 the general environmental regulations that necessitates the implementation of an Environmental Impact Assessment (EIA) studies at the feasibility stage of projects which might cause adverse effects on environment (PME 2003). One type of such projects is coastal resort projects developed directly along seacoasts. Despite the issuance of these regulations, local EIA practitioners are claiming that the current practice of EIA implementation is still weak and there are problems that must be addressed to improve the process. Such underperformance of EIA process has been attributed to the following reasons:

1. EIA study is carried out mainly to satisfy statutory agencies ignoring the fact that the standard practice of EIA usually suggests alternate designs, materials and construction techniques as a mitigation measures. These measures could be tangible (financial) and might incur Mitigation Costs (MCs) that are not considered in the final financial assessment.

2. The decision for approving EIA study is complex because the evaluation of impact significance is both quantitative which is expressed as a regulatory threshold and qualitative that represents subjective values.

There are number of Decision techniques proposed in the literature for the evaluation of projects. Two categories are noteworthy, the economic models (McCowan and Mohamed 2002) and Multi Criteria Decision Making (MCDM) techniques that include Multi Attribute Utility Theory (MAUT) (Keeney and Robilliard 1976), Analytical Hierarchy Process (AHP) (Tsamboulas and Mikroudis 2000), and Neural Networks (NN) (Shepard 2005). Therefore, the main objective of this research is to develop a Decision Support System (DSS) that integrates the financial and environmental impacts into one model to evaluate coastal resort projects along Red Sea coast at feasibility stage.

\section{II - RESEARCH METHODOLOGY}

The methodology followed in this research to achieve research objective is divided into two phases as follows: Phase I- Literature review, and Phase II- System Design \& implementation. Literature review phase establishes the real characteristics and criteria, which should be reflected when developing the proposed DSS of this research. System Design \& implementation phase presents a detailed description of the concept, structure, and mathematical formulation of the proposed system that includes EIA as well as the financial assessment decision components. 


\section{III - SYSTEM DESIGN}

The proposed system is composed of two main components: 1) EIA, and (2) Financial assessment. Every component consists of three modules: 1) Input, (2) knowledge base, and (3) Output module. Figure (1) represents the DSS flowchart.

\section{III-1-EIA System Design}

To start EIA modeling, the Delphi technique was used to obtain an industry feedback from a panel of practitioners on the environmental impacts that have to be used as the input variables for EIA decision component. A list of 24 impacts was collected. Two of them (Water and Air quality) are quantitative and have regulatory thresholds in the Saudi environmental law.

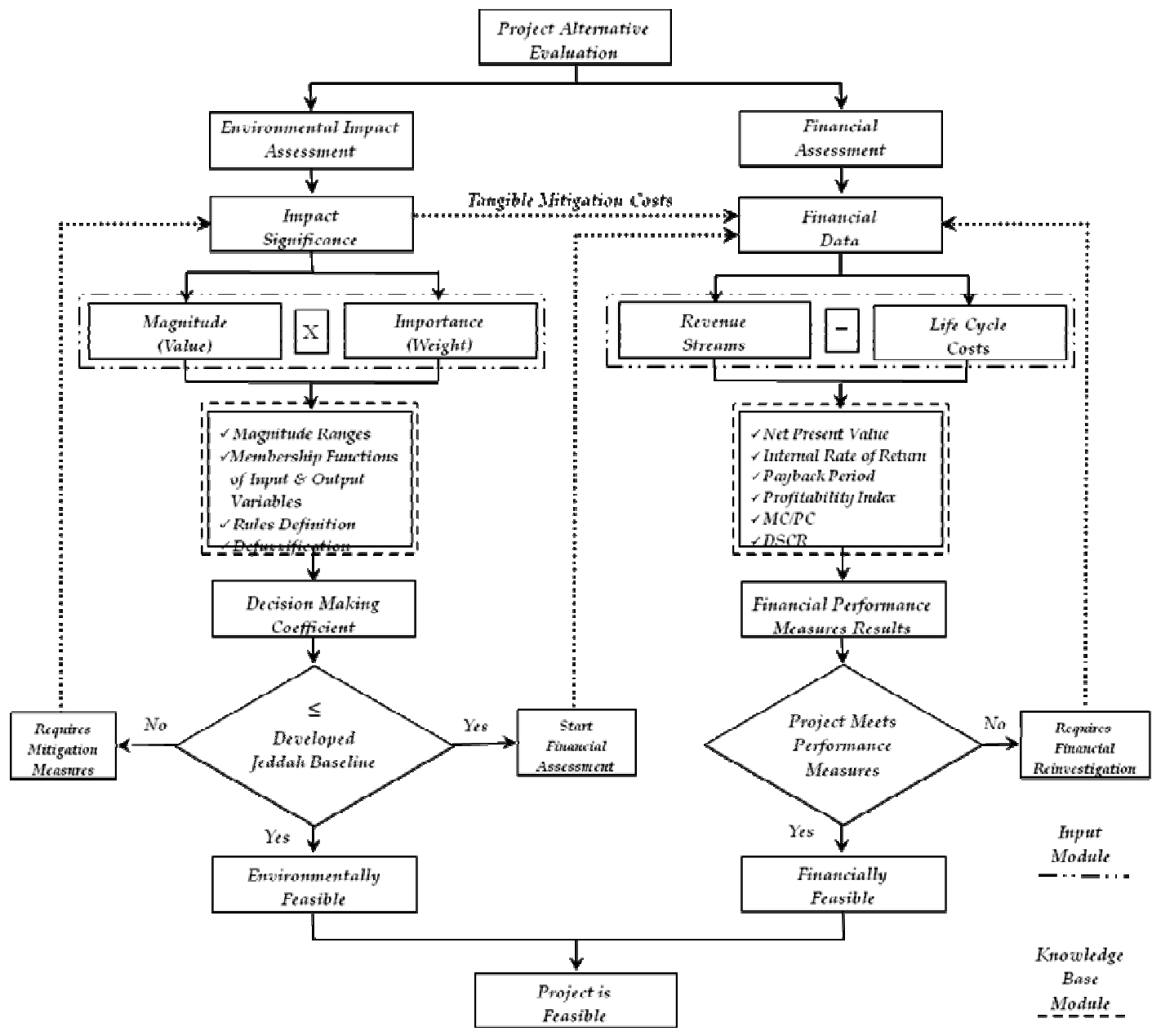

Figure (1) DSS Flowchart 
A domain expert in the field of EIA was consulted to define the parameters of Air and Water quality that should be included in the environmental assessment. The parameters selected by the domain expert for Air quality were Sulphur Dioxide $\left(\mathrm{SO}_{2}\right)$, Nitrogen Dioxide $\left(\mathrm{NO}_{2}\right)$, Particulate Matter $\left(\mathrm{PM}_{10}\right)$ and Carbon Monoxide (CO). The parameters for Water quality were Dissolved Oxygen (DO), Total Suspended Solids (TSS), Ammonia Nitrogen $\left(\mathrm{NH}_{3}-\mathrm{N}\right)$ and Biochemical Oxygen Demand (BOD). The domain expert had been consulted for the grouping of impacts to represent the environmental condition. One of the best ways to find how the decision can be detailed is to arrange these individual variables according to a top down decision tree structured in a hierarchical form as suggested by Boclin and Mello (2006), and Liu et al. (2007). At each node, a group of input variables is aggregated to a new one. This makes four layers of abstraction. The first layer contains the individual input variables concluded from Delphi survey. Every group of variables constitutes several sub groups. Subsequently, sub groups constitute higher order groups of human, ecology, and physical from which the total environmental condition is concluded. All sub groups and groups are considered as the indicators. Figure (2) represents the entire structure of the Impact Decision Tree (IDT) for Jeddah case study.

\section{EIA Input Module}

After defining the input variables, the input values for each individual input variable is estimated by quantifying the impact evaluation of significance. According to UNEP (2002), impact evaluation is a result of multiplying impact importance by impact magnitude. The technique used to determine each impact importance weight is the Pair wise Comparison method. The implementation of this technique on this research study is conducted for every group of variables which constitute a subgroup. The domain expert is invited to conduct his own assessment for all groups of variables with respect to the conditions related to the city of Jeddah. The qualitative scale used to determine impact magnitude ranges from (0) to (100) points. Magnitude and direction are simultaneous. There are two common linguistic scales of possible values or terms used in EIA studies to assess every input variable, five linguistic values scale, and seven linguistic values scale.

The five values scale was adopted as the seven values scale is considered too cumbersome for assessors. The adopted five linguistic values scale is Very Negative, Negative, Neutral, Positive, and Very Positive. Every input variable has a specific range of magnitude corresponding to every linguistic value. The extraction of such knowledge had been conducted from the domain expert who was asked to define the magnitude range corresponding to every linguistic value for each input variable. The quantitative base variables has only three linguistic values of Negative, Neutral and Positive since uncertainty is reduced by the regulation thresholds. The domain expert was asked to conduct his assessment concerning the magnitude values based on the magnitude ranges of the five linguistic values scale with respect to the conditions related to the city of Jeddah. Once importance weighting and magnitude of each input variable are identified, then the crisp input value of each input variable could be calculated by multiplying importance weight by magnitude value for each input variable. As far as the quantitative parameters of air and water quality impacts are concerned, the information of the annual average readings of air quality parameters for 
the year 2009 were taken from PME, and the information of the annual average readings of water quality parameters discharged from the outfalls of the sewage treatment stations for the year 2009 were taken from the Ministry of Water And Electricity. Table (1) represents the crisp values for some of the input variables with respect to the conditions related to the city of Jeddah. The result of multiplying every input variable importance by its magnitude is the quantified evaluation of significance for each variable and is considered as the crisp value, which shall be fuzzified in the knowledge base.

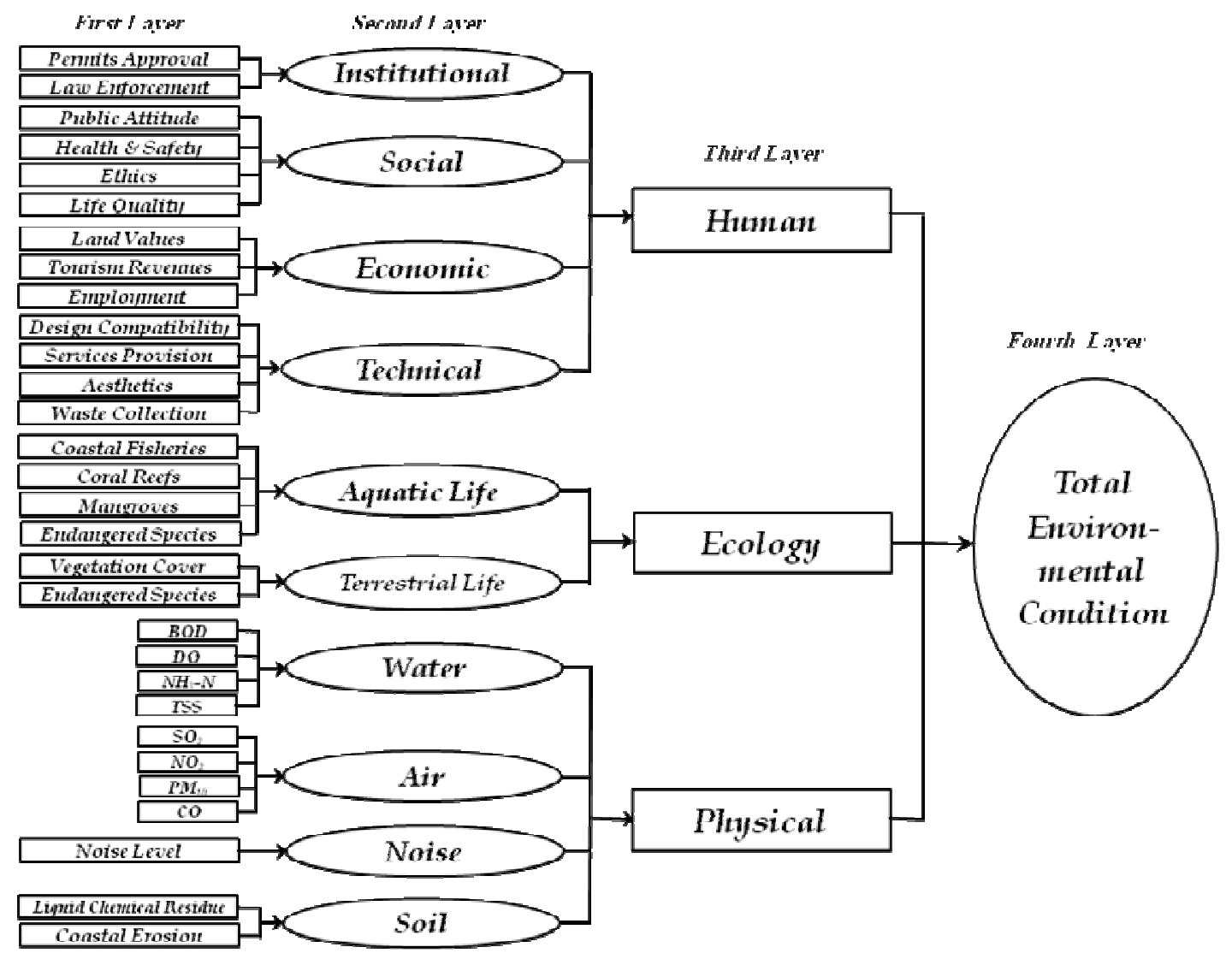

Figure (2) Impact Decision Tree (IDT) for Jeddah Case Study

\section{EIA Knowledge Base}

EIA knowledge base constitutes of membership functions (MBFs) of input and output variables, development of rules and the defuzzification. 
Table (1) Crisp Input Values for some of the Input Variables with Respect to the Conditions Related to the City of Jeddah Note: Grey Color Cells Represent a Reversed Scale Variable

\begin{tabular}{|c|c|c|c|c|c|}
\hline No. & Impact & Influence & Magnitude & Importance & Crisp Input Value \\
\hline 1 & Permits Approval & VN & 80 & 0.50 & 40.00 \\
\hline 2 & Health \& Safety & Neutral & 75 & 0.33 & 24.75 \\
\hline 3 & Public Attitude & Neutral & 50 & 0.21 & 10.50 \\
\hline 4 & Revenues & P & 65 & 0.33 & 21.45 \\
\hline 5 & Waste Collection & Neutral & 70 & 0.30 & 21.00 \\
\hline 6 & Vegetation Cover & Neutral & 50 & 0.43 & 21.50 \\
\hline 7 & Coral Reefs & VN & 90 & 0.29 & 26.10 \\
\hline 8 & Noise Levels & VP & 25 & 1.00 & 25.00 \\
\hline 9 & Coastal Erosion & Neutral & 40 & 0.43 & 17.20 \\
\hline 10 & DO $(\mathrm{mg} / 1)$ & Bad & 3.72 & ---- & 3.72 \\
\hline 11 & SO $_{2}(\mathrm{ppm})$ & Good & 34.58 & ---- & 34.58 \\
\hline
\end{tabular}

\section{- Membership Functions (MBFs)}

For MBFs, Every Input and output variable has several linguistic values and each one is defined by a MBF. The MBFs used are three represented by the linguistic values of Bad, Critical and Good. Therefore, each crisp value obtained from the studied input variable is correlated to the established linguistic values, which the basis varied from zero to 100 . MBFs are represented graphically by different shapes. The Gaussian shape is selected for the developed model. Two reasons for this selection (Shepard, 2005): first, Gaussian MBFs are extensively used in EIA to represent the meaning of measured components in the existing environment and changes predicted under different alternatives. Secondly, they represent real life situations, as they are non zero at all points. The parameters utilized to draw the MFC curve are standard deviation and centre for the Gaussian curve. To define these parameters, the domain expert was asked to define the magnitude ranges for every input and output variable corresponding to the three linguistic values of Bad, Critical and Good. After the definition of these ranges, the calculation of the parameters of the curve was computed using Microsoft Excel.

\section{- Rules Development}

The rules that operate the relationships among the variables have to be established. The methodology used in this research study to develop the rules is the knowledge extraction through domain expert. In each rule block of fuzzy knowledge base, the composition of the input and output variables consist of two main parts: If (antecedent) and Then (consequent). While the If part of the rule describes the situation for which it is designed, the Then part describes the action of the fuzzy system in this situation. There are 14 rule blocks of fuzzy knowledge bases that operate the relationships among the variables. In order to operate the fuzzy sets, several meetings had been held with the domain expert to extract the rules. The conditions established by the rule 
blocks were assumed by the domain expert to be of the restriction type with the And sets combination. And means that we have an intersection of two sets. The knowledge base rule for water quality can be exemplified. The parameters of water quality are DO, BOD, TSS, and $\mathrm{NH}_{3}-\mathrm{N}$. According to the knowledge of the domain expert, DO and BOD are complements to each other and should have the same condition whether Good or Bad. Therefore, any contradicting relationship between them in the rule set does not reflect real life conditions. Moreover, DO is a determinant parameter that affects the condition of the resulting water quality in the sense that DO reflects the level of Oxygen in water, therefore, if Oxygen level is $\mathrm{Bad}$, then this means that aquatic and marine life is exposed to death hazards and vice versa. Accordingly, 37 rules representing the relationships among water quality parameters were developed. A sample of the rules developed for the water quality knowledge base is shown in Table (2).

Table (2) Sample of Water Quality Knowledge Base Rules

\begin{tabular}{|c|c|c|c|c|c|c|c|c|c|}
\hline No. & DO & Op* & $\mathrm{NH}_{3}-\mathrm{N}$ & Op* & TSS & Op* & BOD & THEN & $\begin{array}{c}\text { Water } \\
\text { Quality }\end{array}$ \\
\hline 1 & Bad & ---- & ---- & ---- & ---- & ---- & ---- & THEN & Bad \\
\hline 2 & Critical & AND & Bad & AND & Good & AND & Critical & THEN & Critical \\
\hline 3 & Critical & AND & Critical & AND & Good & AND & Critical & THEN & Critical \\
\hline 4 & Good & AND & Bad & AND & Critical & AND & Good & THEN & Good \\
\hline 5 & Good & AND & Critical & AND & Critical & AND & Good & THEN & Good \\
\hline 6 & Critical & AND & Good & AND & Critical & AND & Good & THEN & Critical \\
\hline 7 & Good & AND & Good & AND & Critical & AND & Good & THEN & Good \\
\hline 8 & Critical & AND & Bad & AND & Good & AND & Good & THEN & Good \\
\hline 9 & Good & AND & Bad & AND & Good & AND & Good & THEN & Good \\
\hline 10 & Critical & AND & Good & AND & Bad & AND & Good & THEN & Critical \\
\hline 11 & Good & AND & Good & AND & Bad & AND & Good & THEN & Good \\
\hline
\end{tabular}

$* \mathrm{Op}=$ Operator

\section{- Defuzzification}

The results of the operation in these knowledge base rule blocks are represented by linguistic values, which need to be converted back to a crisp number. This resultant number represents the existing environmental condition or the projected future conditions of the alternative. The process of representing a consequent fuzzy set as a crisp number is called defuzzification. The value of the consequent set can be determined by several methods. According to Shepard (2005), the center of gravity is suitable for the semantics inherent in an EIA and makes a good default that will be appropriate most of the time. This defuzzified crisp value is considered as the Decision Making Coefficient (DMC) for the EIA system development. This DMC value represents the magnitude of relative severity on the environment. The higher the DMC magnitudes, the change to environment condition tends to be bad and vice versa. Concerning the baseline for the existing conditions of the city of Jeddah, the defuzzified value resulted from the inputted crisp values which was based on the assessment of the domain expert for importance weights and magnitude values for all 
input variables was (56.04). This defuzzified value is called Jeddah DMC and was calculated by simulink of Matlab software. Jeddah DMC is embedded in the knowledge base of the EIA system design and considered as a standard baseline or benchmark from which any project alternative is compared and evaluated.

\section{ElA Output Module}

The output module of EIA decision component shows to the user the resultant DMC for the project alternative under investigation. This DMC has a priority in evaluation for the comprehensive assessment of coastal resort projects. This DMC is compared with the baseline of the city of Jeddah which is developed in this research work. If DMC for the project alternative is greater than the baseline of the city of Jeddah, then the alternative project is environmentally unacceptable and an additional mitigation measures are to be proposed and consequently tangible MCs are to be estimated until the DMC for the project alternative becomes equal to or less than the baseline of the city of Jeddah. If DMC for the project alternative is equal to or less than Jeddah baseline, then the project alternative is environmentally acceptable and the estimated tangible MCs are satisfactory and shall be used as an input in the financial assessment decision component.

\section{III-1- Financial Assessment System Design Input Module}

The input module begins if the project is environmentally acceptable. Then, parameters of life cycle costs including mitigation measures costs and project revenues are to be defined. The current practice in the local market of KSA concerning the financial parameters identified in the financial assessment to conclude the financial performance measures of a project are as follows:

- Cash Out (Costs) that includes land value, project costs, loan and the debt service and annual operating costs.

- Cash In (Revenues) that includes loan amount, annual revenues and the project salvage value.

\section{Knowledge Base}

The knowledge base module of the financial assessment performs the function of the computation of the mathematical formulae concerning the financial measures. These measures satisfy the several parties involved in the decision making of the project including:

- Equity Holders are satisfied with the Net Present value (NPV), Internal Rate of Return (IRR), Payback Period (PBP), Profitability Index (PI), and ratio of Mitigation Cost/Project Cost (MC/PC).

- Lenders are satisfied with Debt Service Coverage Ratio (DSCR).

\section{The Output Module}

The output module of the financial assessment model has to show the results of the several financial performance measures. The criteria for the acceptability of these performance measures are as follows:

- $N P V$ : Positive numbers. 
- IRR: The resulting Rate has to be greater than the loan interest rate of the project alternative.

- PBP: The resulting Number of Years has to be suitable to the project investor.

- PI: Greater than one.

- $M C / P C$ : Less than or equal to $5 \%$.

- DSCR: At least equals to or greater than one.

\section{IV - VALIDATION}

The system design of EIA decision component had been verified by conducting several iterations of trial and error process to ensure that results concluded are logical. The first trial concluded that the decision range was not logical since the result of the two iterations of worst and best conditions lie only within number (54). The second trial concluded that the decision range lies between (48.83-57.50) which is logical. Moreover, the resultant DMC for the city of Jeddah (i.e. 56.04) lies within the decision range concluded. Concerning the three case study projects, the resultant DMC for the first case study project is (51.34), the DMC for the second case study project is (52.45), and lastly, the DMC for the third case study project is (54.88). Therefore, the results of the three DMCs for the three case study projects were all between (48.8357.50). Analysis of the DMC results for the three case study projects are detailed later in this section. Figure (3) represents the process of trial and error. The accuracy of financial formulae calculated by CACRP were verified by comparing the program's assessment results for the three case study projects with financial calculations produced by Excel spreadsheet for all three projects. Table (3) represents a comparison of financial assessment results. The comparison shows clearly that all financial performance measures calculated by CACRP are typical to those calculated by Excel Spreadsheet. Three real life case study projects are used to validate the developed system. A set of criteria were developed to ensure that the case study projects selected would be effective in validating the developed system. These criteria include data availability (EIA and financial), and various sizes of projects. As far as the assessment of EIA model, the assessment of magnitude and importance weight of each input variable is conducted by the senior manager of each project. Table (4) represents the crisp value calculation for the three case study projects. The information pertaining to financial parameters for the three projects are collected from the management of each project. Table (5) represents the financial information for the three case study projects. 


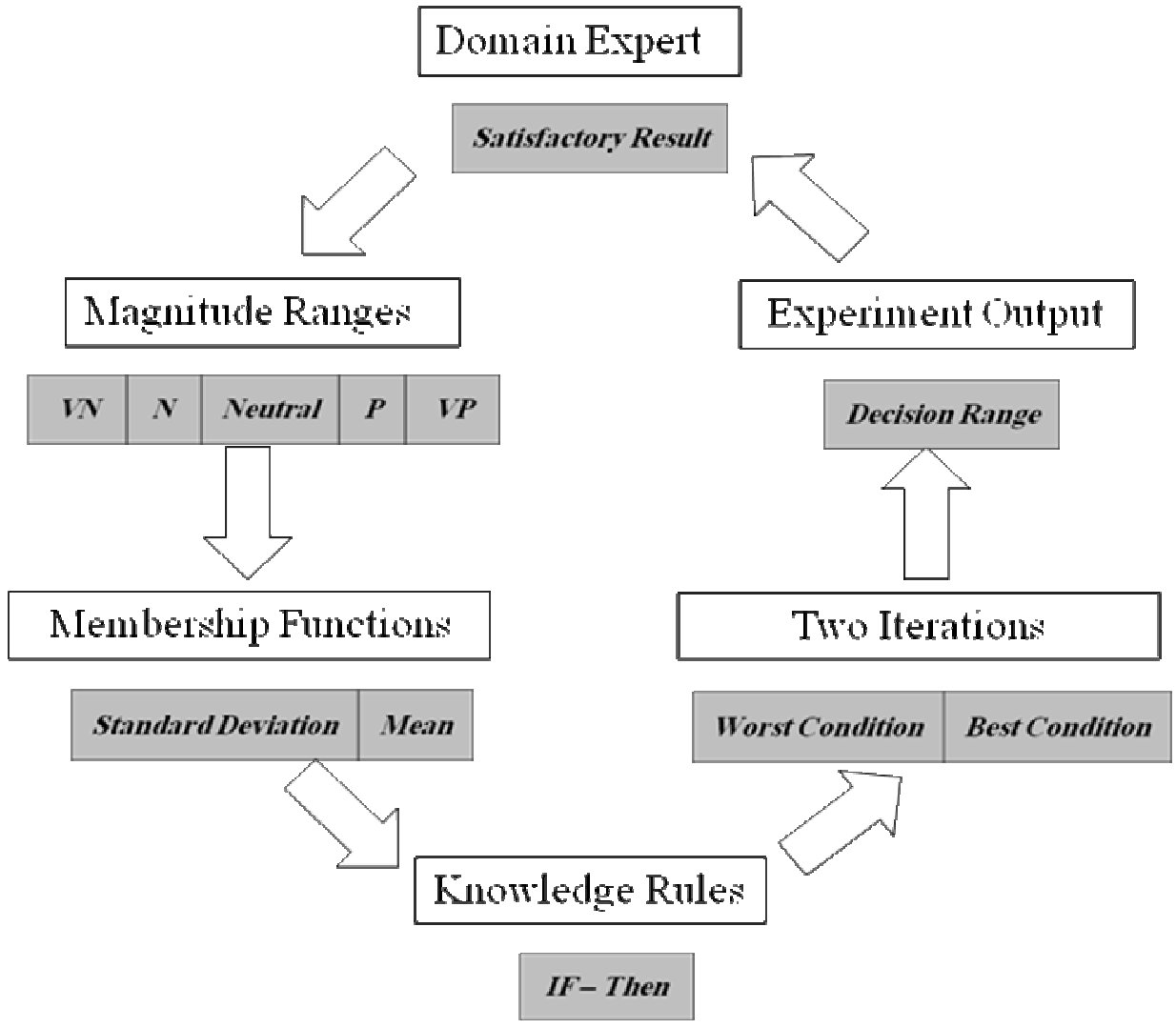

Figure (3) Process of Trial and Error

Table (3) Comparison of Financial Assessment Results

\begin{tabular}{|l|c|c|c|c|c|c|}
\hline \multirow{2}{*}{$\begin{array}{c}\text { Financial } \\
\text { Performance } \\
\text { Measure }\end{array}$} & \multicolumn{2}{|c|}{$\begin{array}{c}\text { Case Study } \\
\text { One }\end{array}$} & \multicolumn{2}{c|}{$\begin{array}{c}\text { Case Study } \\
\text { Two }\end{array}$} & \multicolumn{2}{c|}{$\begin{array}{c}\text { Case Study } \\
\text { Three }\end{array}$} \\
\cline { 2 - 7 } & CACRP & Excel $\odot$ & CACRP & Excel $\odot$ & CACRP & Excel $\odot$ \\
\hline 1. NPV & 135.9 & 135.9 & 7.66 & 7.66 & 1.89 & 1.89 \\
\hline 2. IRR & 18.51 & 18.51 & 10.58 & 10.58 & 10.39 & 10.39 \\
\hline 3. PI & 1.22 & 1.22 & 1.03 & 1.03 & 1.01 & 1.01 \\
\hline 4. MC/PC & 3.36 & 3.36 & 2.05 & 2.05 & 1.66 & 1.66 \\
\hline 5. DSCR & 12.65 & 12.65 & 2.99 & 2.99 & 2.09 & 2.09 \\
\hline 6. PBP & 4 & 4 & 13 & 13 & 13 & 13 \\
\hline
\end{tabular}


Table (4) Crisp Value Calculation for the Three Case Study Projects

\begin{tabular}{|c|c|c|c|c|c|c|c|c|c|c|}
\hline \multirow[b]{2}{*}{ No. } & \multirow[b]{2}{*}{ Impact } & \multicolumn{3}{|c|}{ Case Study One } & \multicolumn{3}{|c|}{ Case Study Two } & \multicolumn{3}{|c|}{ Case Study Three } \\
\hline & & 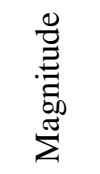 & 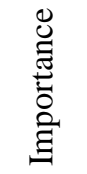 & 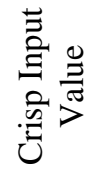 & $\begin{array}{l}\stackrel{0}{0} \\
\stackrel{\Xi}{\Xi} \\
.00 \\
\Sigma \\
\Sigma\end{array}$ & 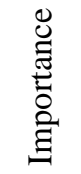 & 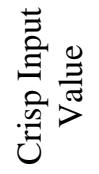 & $\begin{array}{l}\stackrel{0}{0} \\
\stackrel{\Xi}{\Xi} \\
.00 \\
\Sigma \\
\Sigma\end{array}$ & 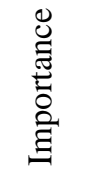 & 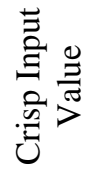 \\
\hline 1 & Permits Approval & 5 & 0.57 & 2.85 & 35 & 0.57 & 19.95 & 90 & 0.63 & 56.70 \\
\hline 2 & Law Enforcement & 90 & 0.43 & 38.70 & 90 & 0.43 & 38.70 & 95 & 0.37 & 35.15 \\
\hline 3 & Health \& Safety & 10 & 0.35 & 3.50 & 7 & 0.34 & 2.38 & 20 & 0.33 & 6.60 \\
\hline 4 & Public Attitude & 90 & 0.21 & 18.90 & 55 & 0.20 & 11.00 & 55 & 0.21 & 11.55 \\
\hline 5 & Ethics & 45 & 0.22 & 9.90 & 45 & 0.23 & 10.35 & 45 & 0.21 & 9.45 \\
\hline 6 & Quality of Life & 100 & 0.22 & 22.00 & 90 & 0.23 & 20.70 & 50 & 0.26 & 13.00 \\
\hline 7 & Land Values & 60 & 0.23 & 13.80 & 60 & 0.25 & 15.00 & 60 & 0.31 & 18.60 \\
\hline 8 & Revenues & 100 & 0.50 & 50.00 & 95 & 0.38 & 36.10 & 70 & 0.33 & 23.10 \\
\hline 9 & Employment & 95 & 0.27 & 25.65 & 95 & 0.37 & 35.15 & 65 & 0.36 & 23.40 \\
\hline 10 & Design Comp. & 95 & 0.24 & 22.80 & 60 & 0.23 & 13.80 & 40 & 0.23 & 9.20 \\
\hline 11 & Services Provision & 100 & 0.27 & 27.00 & 95 & 0.24 & 22.80 & 70 & 0.29 & 20.30 \\
\hline 12 & Aesthetics & 95 & 0.22 & 20.90 & 95 & 0.25 & 23.75 & 50 & 0.20 & 10.00 \\
\hline 13 & Waste Collection & 100 & 0.27 & 27.00 & 95 & 0.28 & 26.60 & 60 & 0.30 & 18.00 \\
\hline 14 & Vegetation Cover & 10 & 0.50 & 5.00 & 30 & 0.60 & 18.00 & 95 & 0.43 & 40.85 \\
\hline 15 & $\begin{array}{l}\text { End. Species } \\
\text { (Terrestrial) }\end{array}$ & 10 & 0.50 & 5.00 & 90 & 0.40 & 36.00 & 90 & 0.57 & 51.30 \\
\hline 16 & Coral Reefs & 90 & 0.29 & 26.10 & 90 & 0.34 & 30.60 & 90 & 0.29 & 26.10 \\
\hline 17 & Coastal Fisheries & 25 & 0.18 & 4.50 & 70 & 0.20 & 14.00 & 70 & 0.18 & 12.60 \\
\hline 18 & Mangroves & 90 & 0.26 & 23.40 & 90 & 0.24 & 21.60 & 90 & 0.26 & 23.40 \\
\hline 19 & $\begin{array}{l}\text { End. Species } \\
\text { (Aquatic) }\end{array}$ & 90 & 0.27 & 24.30 & 90 & 0.22 & 19.80 & 90 & 0.28 & 25.20 \\
\hline 20 & Noise Levels & 15 & 1.00 & 15.00 & 25 & 1.00 & 25.00 & 55 & 1.00 & 55.00 \\
\hline 21 & $\begin{array}{c}\text { Liquid Chemical } \\
\text { Residue }\end{array}$ & 10 & 0.50 & 5.00 & 10 & 0.50 & 5.00 & 20 & 0.57 & 11.40 \\
\hline 22 & Coastal Erosion & 10 & 0.50 & 5.00 & 15 & 0.50 & 7.50 & 50 & 0.43 & 21.50 \\
\hline 23 & DO (mg/l) & 8.90 & -- & 8.90 & 8.40 & -- & 8.40 & 8.10 & -- & 8.10 \\
\hline 24 & $\mathrm{NH}_{3}-\mathrm{N}(\mathrm{mg} / \mathrm{l})$ & 0.80 & -- & 0.80 & 0.70 & -- & 0.70 & 0.40 & -- & 0.40 \\
\hline 25 & TSS (mg/l) & 11.50 & -- & 11.50 & 10.75 & -- & 10.75 & 12.80 & -- & 12.80 \\
\hline 26 & BOD (mg/l) & 17.90 & -- & 17.90 & 19.60 & -- & 19.60 & 18.70 & -- & 18.70 \\
\hline 27 & $\mathrm{SO}_{2}(\mathrm{ppm})$ & 24.35 & -- & 24.35 & 31.66 & -- & 31.66 & 66.00 & -- & 66.00 \\
\hline 28 & $\mathrm{NO}_{2}(\mathrm{ppm})$ & 47.80 & -- & 47.80 & 58.71 & -- & 58.71 & 87.00 & -- & 87.00 \\
\hline 29 & $\mathrm{PM}_{10}\left(\mathrm{mg} / \mathrm{m}^{3}\right)$ & 16.44 & -- & 16.44 & 12.21 & -- & 12.21 & 44.80 & -- & 44.80 \\
\hline 30 & $\mathrm{CO}\left(\mathrm{mg} / \mathrm{m}^{3}\right)$ & 4.50 & -- & 4.50 & 4.80 & -- & 4.80 & 4.20 & -- & 4.20 \\
\hline
\end{tabular}




\section{Table (5) Financial Information for the Three Case Study Projects}

\begin{tabular}{|c|c|c|c|}
\hline Financial Parameter & $\begin{array}{c}\text { Case Study } \\
\text { One }\end{array}$ & $\begin{array}{c}\text { Case Study } \\
\text { Two }\end{array}$ & $\begin{array}{c}\text { Case Study } \\
\text { Three }\end{array}$ \\
\hline 1. Land Value & 165.000 & 40.000 & 9.000 \\
\hline 2. Project Costs & -- & -- & -- \\
\hline a. Construction Costs & 234.100 & 132.144 & 73.736 \\
\hline b. Pre operating Costs & -- & -- & -- \\
\hline - Recruitment & 0.600 & 0.250 & 0.135 \\
\hline - Design Fees & 3.500 & 1.000 & 0.100 \\
\hline - Consultancy Fees & 8.500 & 2.000 & 0.350 \\
\hline - Marketing & 0.350 & 0.050 & 0.000 \\
\hline - Miscellaneous & 1.250 & 0.175 & 0.045 \\
\hline c. Mitigation Costs & 8.700 & 2.856 & 1.264 \\
\hline d. Working Capital & 1.930 & 0.970 & 0.506 \\
\hline 3. Annual Loan Repayment & 57.846 & 15.227 & 7.683 \\
\hline 4. Annual O \& M Costs (before Amortization) & 19.304 & 9.704 & 5.060 \\
\hline 5. Annual O \& M Costs (Amortized) & 16.464 & 9.009 & 4. 934 \\
\hline 6. Expected Sales of Residential Units & 540.000 & 0.000 & 0.000 \\
\hline 7. Annual Revenues & 18.800 & 27.725 & 14.800 \\
\hline 8. Salvage value (End of Year 15) & 389.258 & 189.999 & 66.025 \\
\hline 9. Loan Amount & 225.000 & 85.000 & 40.000 \\
\hline
\end{tabular}

O \& M: Operation \& Maintenance

Note: All values are in Millions SR

Once all three project data files has been created and inputted in CACRP for the three case study projects, the analysis could be conducted for the evaluation for the three projects. The results for the evaluation of the three projects are presented in Figure (4). 


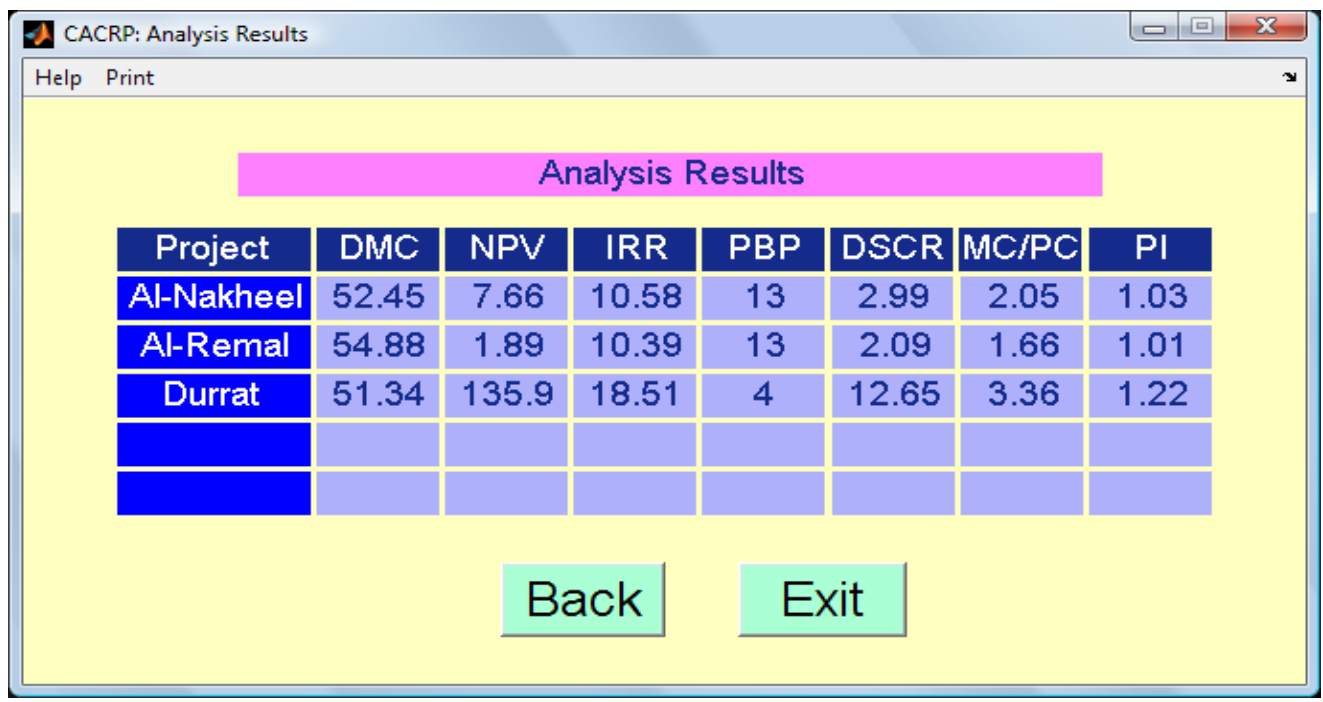

Figure (4) CACRP Assessment Results

CACRP evaluated the three projects according first to the Decision Making Coefficient (DMC) for the environmental assessment as follows:

1. Case study one - Durrat Al-Arous project with the lowest DMC of (51.34);

2. Case study two - Al-Nakheel project with a DMC of (52.45); and

3. Case study three $-\mathrm{Al}$-Remal project with the highest DMC of (54.88).

The DMC for every project was less than the DMC of the city of Jeddah which is equal to (56.04). Therefore, all three projects were environmentally acceptable and feasible which allowed the financial assessment for the three projects to be initiated and analyzed. Looking at the financial assessment of the projects, from the equity holder's perspective, case study three project (Al-Remal) is the least feasible with the lowest NPV of SR 1.89 millions and IRR of (10.39\%). The most feasible project is case study one (Durrat Al-Arous) project with an NPV of SR 135.90 millions and IRR of $(18.51 \%)$. From the lender's perspective, the average DSCR should at least equal to one or greater for the project to be considered feasible. It is evident that from the results of DSCR that lenders would consider case study one (Durrat Al-Arous) project is highly feasible with an average annual DSCR of (12.65) and case study three (AlRemal) project is the least feasible with an average annual DSCR of (2.09).

From an overall assessment perspective, case study one project is the most feasible option due to the following achievements of performance measures:

1. Environmental DMC = (51.34) is less than Jeddah DMC (56.04) and the least among other case studies;

2. $\mathrm{NPV}=\mathrm{SR} .135 .90$ is positive and the highest among other case studies;

3. $\mathrm{IRR}=18.51 \%$ is greater than project interest rate $(9 \%)$;

4. $\mathrm{PI}=1.31$ is greater than 1 ;

5. $\mathrm{MC} / \mathrm{PC}=3.36 \%$ is less than $5 \%$ and hence within the acceptable limit;

6. $\mathrm{PBP}=4$ which is excellent; and

7. $\mathrm{DSCR}=12.65$ is greater than one. 
The second feasible project is case study two (Al-Nakheel) project and the least feasible project is case study three (Al-Remal) project. Table (6) represents a comparison of final assessment results.

Table (6) Results of Assessment Measures

\begin{tabular}{|c|c|c|c|c|c|c|c|}
\hline \multirow{2}{*}{$\begin{array}{c}\text { Proposed } \\
\text { Project }\end{array}$} & \multicolumn{7}{|c|}{ ASSESSMENT MEASURES } \\
\cline { 2 - 8 } & $\begin{array}{c}\text { EIA } \\
\text { DMC }\end{array}$ & NPV & IRR & PBP & PI & DSCR & $\frac{\text { MC }}{\text { PC }}$ \\
\hline $\begin{array}{c}\text { Case Study } \\
\text { One }\end{array}$ & 51.34 & 135.9 & 18.51 & 4 & 1.22 & 12.65 & 3.36 \\
\hline $\begin{array}{c}\text { Case Study } \\
\text { Two }\end{array}$ & 52.45 & 7.66 & 10.58 & 13 & 1.03 & 2.99 & 2.05 \\
\hline $\begin{array}{c}\text { Case Study } \\
\text { Three }\end{array}$ & 54.88 & 1.89 & 10.39 & 13 & 1.01 & 2.09 & 1.66 \\
\hline BASELINE & $\mathbf{5 6 . 0 4}$ & \multicolumn{7}{|c|}{ JEDDAH EXISTING ENVIRONMENTAL CONDITIONS } \\
\hline
\end{tabular}

\section{V - CONCLUSIONS}

This research study developed a DSS that integrates the financial and environmental impacts into one model to evaluate coastal resort projects along Red Sea coasts at feasibility stage. An environmental base line for the existing conditions of the city of Jeddah was developed utilizing the expertise of a domain expert to operate the fuzzy logic approach. This developed baseline was used as benchmark for the evaluation of project alternatives and proposals. The system is validated using three existing projects. The results showed that the system is working professionally.

\section{VI - REFERENCES}

1. Boclin, A., and Mello, R. (2005) A Decision Support Method for Environmental Impact Assessment using a Fuzzy Logic Approach, Ecological Economics, Vol. 58, pp 170-181.

2. Keeney, R.L., and Robilliard, G.A. (1976) Assessing and Evaluating Environmental Impacts at Proposed Nuclear Power Plant Sites, Journal of Environmental Economics and Management, Vol. 4, pp 153-166.

3. Liu, K., Haung, S., and Liang, H. (2007) A Qualitative Decision Support for Environmental Impact Assessment using Fuzzy Logic, Environmental Information Archives, Vol. 5, pp 469-479.

4. Mc Cowan, A., and Mohamed, S. (2002) Evaluation of Build- OperateTransfer (BOT) Project Opportunities in Developing Countries, In proceedings of CIB W107, 11-13 November, South Africa, pp 377-388. 
5. PME (2003) The Regulations of the Overall System of the Environment in Saudi Arabia, Jeddah: PME.

6. Shepard, R.B. (2005) Quantifying Environmental Impact Assessment Using Fuzzy Logic, Springer, New York.

7. Tsamboulas, D., and Mikroudis, G. (2000) EFECT - evaluation framework of environmental impacts and costs of transport initiatives Transportation Research, Part D 5, pp 283-303.

8. UNEP (2002) Environmental Impact Assessment, $2^{\text {nd }}$ Ed., Training Resource Manual, USA. 


\section{نظام دعم القرار لتقويم شامل لمشاريع المنتجعات الساحلية بمدينة جدة}

تقويم المشروع يعتبر التأثثرات المالية والتأثثرات البيئية ذات العلاقة بالجانب الإنساني، الطبيعي، والحيوي.

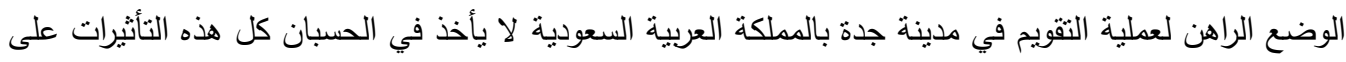
الرغم من صدور الأنظمة البيئية العامة عام 2001 والتي تستلزم تطبيق دراسات التقويم البيئي خلال مرحلة إعداد دراسات الجدوى للمشاريع المتوقع أن تؤئز سلبا على البيئة. الهدف من هذا البحث نطوير نظام لدعم القرار بدمج هذه التأثيرات في نموذج موحد لتقويم مشاريع المنتجعات

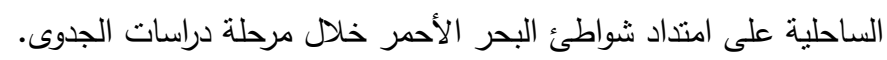

النظام المقترح ينكون من جزئيين أساسيين ألا وهما التقويم البيئي والمالي. أولا، يقوَم النظام التأثيرات البيئية للمشروع باستخدام تقنية النموذج الغامض وذلك بحساب معامل صنع القرار. ثقارن قيمة هذا المعامل بالمعيار

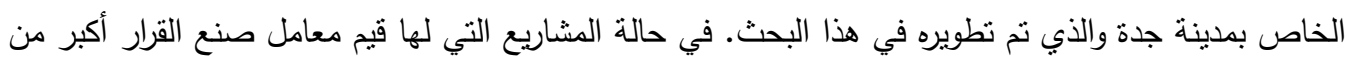
معيار مدينة جدة فيتم اقتراح الإجراءات الاحترازية المناسبة للحد من التأثثرات البيئية السلبية. ثانيا، يقوَم النظام المشاريع التي ليس تأثثرات بيئية سلبية من الناحية المالية وذلك بحساب القيمة الحالية الصافية، معدل العائد الداخلي، فترة استرجاع رأس المال، مؤشر الربحية، نسبة تغطية خدمة الدين وناتج قسمة التكاليف الاحترازية على لئى تكلفة المشروع. ختاما تم التحقق من النظام المطور باستخدام ثلاثة مشاريع سياحية قائمة في مدينة جدة حيث أظهرت النتائج أن الثلاثة مشاريع كانت مقبولة ومجدية من الجانب البيئي والمالي. 
